\title{
Preliminary assessment of surf-zone and estuarine line- fish species of the Dwesa-Cwebe Marine Protected Area, Eastern Cape, South Africa
}

\begin{abstract}
Authors:
Jan A. Venter ${ }^{1,2}$

Bruce Q. Mann ${ }^{3}$

Affiliations:

${ }^{1}$ Department of Biodiversity Conservation, Eastern Cape Parks and Tourism Agency,

South Africa

${ }^{2}$ School of Life Sciences, University of Kwazulu-Natal, Westville Campus, South Africa

${ }^{3}$ Oceanographic Research Institute, Marine Parade, South Africa

Correspondence to: Jan Venter

Email:

jan.venter@ecpta.co.za

Postal address:

PO Box 11235, East London

5213, South Africa

Dates:

Received: 30 June 2011 Accepted: 02 June 2012

Published: 10 Sept. 2012

How to cite this article: Venter, J.A. \& Mann, B.Q., 2012, 'Preliminary assessment of surf-zone and estuarine line-fish species of the Dwesa-Cwebe Marine Protected Area, Eastern Cape, South Africa', Koedoe 54(1), Art. \#1059, 10 pages. http://dx.doi.org/10.4102/ koedoe.v54i1.1059
\end{abstract}

C 2012. The Authors. Licensee: AOSIS OpenJournals. This work is licensed under the Creative Commons Attribution License.
A preliminary assessment of surf-zone and estuarine line fish was carried out in the DwesaCwebe Marine Protected Area (MPA), on the Wild Coast, South Africa. The purpose was to provide baseline data on inshore line-fish stocks in the MPA. A total of 28 species was recorded, of which $53 \%$ have a conservation status reflecting some concern and $43 \%$ are endemic to southern Africa. This highlights the value of the MPA for protection of important line-fish species. Within the MPA, localised differences were detected in species diversity, size frequency and catch per unit effort between unexploited and illegally exploited areas. These differences were more prominent in slow growing, long-lived species. It thus appears that illegal exploitation is negatively affecting fish populations within the MPA, which counteract and potentially could eliminate the benefits of fish protection typically associated with no-take MPAs. These results highlight the need for improved law enforcement and better communication with neighbouring communities to increase awareness. It is further recommended that the current no-take status of the MPA should be maintained. In addition, baseline fisheries information was collected on certain fish species that could be used to inform future conservation management of the MPA.

Conservation implications: The Dwesa-Cwebe Marine Protected Area is unique and important for the conservation of key surf zone and estuarine fish species. However there is a significant risk to the fish populations due to illegal exploitation. Key interventions should include enhanced law enforcement but, more important, the creation of alternative livelihoods and long term sustainable benefits to local communities.

\section{Introduction}

Research and monitoring of marine biodiversity features is an essential component of the management of marine protected areas (MPAs). This is particularly true for inshore line-fish species, as they are predominantly over-exploited (Cowley, Brouwer \& Tilney 2001). Marine protected areas can play an important role in providing a refuge for over-exploited line-fish stocks and the 'spillover effect' is an important ecosystem service provided to adjacent exploited areas (Bennett \& Attwood 1991; Cowley et al. 2001; McClanahan \& Mangi 2000; Kerwath et al. 2008). Many surf-zone line-fish species have both recreational and subsistence value and could thus be considered to have significant socio-economic importance along the Wild Coast (Fielding et al. 1994; Pradervand 2004).

The Dwesa-Cwebe MPA was formally declared as a marine reserve in 1991 (Transkei Environmental Conservation Decree No. 9 of 1992), and re-proclaimed in terms of the Marine Living Resources Act (Act No. 18 of 1998) in 2000. The entire reserve is currently zoned as a no-take MPA, where no consumptive marine resource use is permitted. However, enforcement has been problematic since the MPA's proclamation and certain sections of the MPA continue to be utilised illegally by local community members, hotel guests and holiday cottage owners residing within the Dwesa-Cwebe Nature Reserve. Currently, considerable pressure is being placed on management authorities to rezone certain sections of the MPA to accommodate subsistence and recreational fishing. However, a recent report strongly advised against such action, due to the potential negative impacts on line fish populations (Fielding 2010).

Little data exist on the surf-zone and estuarine line-fish stocks within the MPA, and thus a monitoring project was initiated at the beginning of 2009 with the following objectives, (1) to provide baseline data on the surf-zone and estuarine line-fish species assemblage, (2) to document size composition and relative abundance of key inshore line-fish species and (3) to gain an understanding of the impacts of current illegal fishing on inshore line-fish species within 
the MPA. This paper presents the preliminary results of this project for the years 2009-2010.

\section{Study area}

The Dwesa-Cwebe Marine Protected Area is located on the Wild Coast, approximately $120 \mathrm{~km}$ northeast of East London on the east coast of South Africa (Figure 1). The MPA incorporates approximately $16 \mathrm{~km}$ of mainly rocky shore coastline and extends 6 nautical miles $(10.8 \mathrm{~km})$ out to sea.

The MPA is located in a transition zone between the Agulhas and Natal bioregions (Lombard et al. 2004; Maree, Booth \& Whitfield 2000). Because of its location within this region of transition, the MPA is considered to be in a sensitive area that is not replicated elsewhere on the coast of South Africa (Fielding 2010). The Mbashe Estuary, situated centrally within the MPA, ranks 28th in terms of the conservation importance of estuaries in South Africa (Turpie et al. 2002). The surf-zone adjacent to the Mbashe mouth is also considered to be a key spawning aggregation site for white steenbras (Lithognathus lithognathus), the stock of which has collapsed (Bennett 1993; Mann 2000).

\section{Research method and design Study sites}

Two sample sites were initially identified where research fishing took place. These were the Cwebe sample site and the Dwesa sample site, located to the north-east and south-west of the Mbashe Estuary mouth respectively (Figure 1). Each sample site was $3.6 \mathrm{~km}$ long and incorporated representative portions of the available inshore habitats. It was known from field ranger patrol data, law enforcement records and from physical signs left by shore fishers, that the Cwebe sample site received more illegal fishing pressure than the Dwesa sample site (ECPTA, unpublished data). At the end of 2010, a third sample site, namely the Mbashe Estuary, which stretches from the estuary mouth up to the old pont $\pm 5 \mathrm{~km}$ upstream, was also incorporated into the study area (Figure 1).

\section{Catch and effort data}

Detailed catch and effort data were collected by means of research fishing, similar to the methods described by Attwood (2003). Four-day sampling trips took place in the months January, May, July and October 2009 as well as February, August and October 2010. The number of anglers used during sampling trips varied between 4 and 8. Fishing took place during daylight hours (between 07:00 and 17:00) using a variety of baits (mainly pilchards, squid, prawns and red bait). An equal amount of time, in terms of the number of days, was spent fishing in the different sampling areas. All fish caught were carefully handled, measured to the nearest millimetre and released unharmed. Barbless hooks were used to reduce release mortality. Catch per unit effort (CPUE) was calculated as the number of fish caught per angler per hour. It was assumed that CPUE was directly related to relative abundance and takes the form CPUE $=N q$, where $N$ is abundance and $q$ is the catch ability factor that mediates the relationship (Bennett \& Attwood 1991).

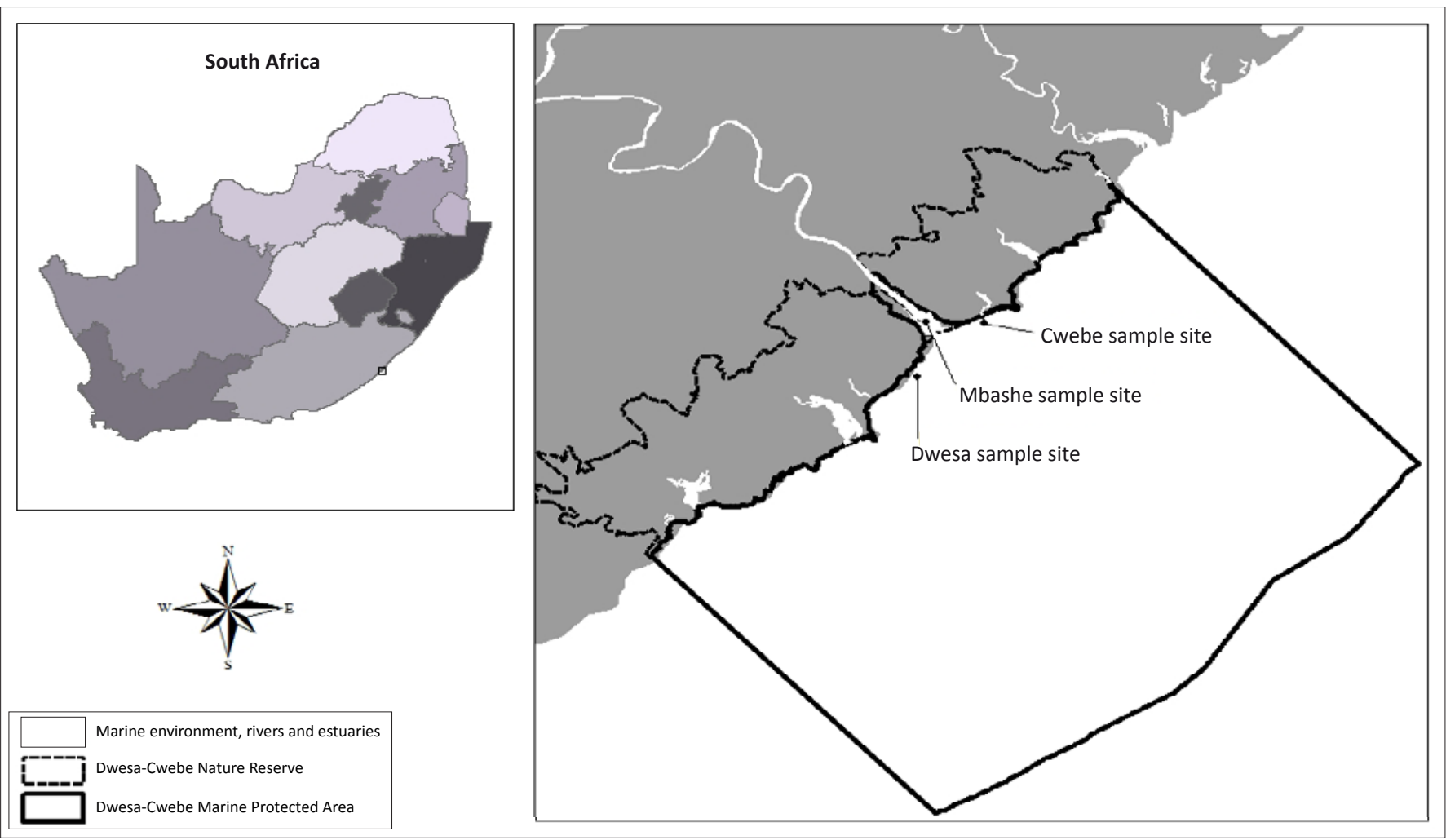

FIGURE 1: The location of the Dwesa-Cwebe Marine Protected Area with the Dwesa, Cwebe and Mbashe sampling sites indicated. 
The catch per unit effort CPUE was calculated as:

CPUE $=\frac{C}{E}$

where $E$ was calculated as $\sum H_{i}$ per day with $H$ as the hours fished by angler $i, C$ was calculated as $\sum F_{i}$ per day where $F$ is the number of fish caught by angler $i$.

Sampling effort was spread over the sampling sites by setting time constraints. Once an angler started fishing at an area within the sample site, he had to stay there for at least one hour but could not stay longer than two hours. When an angler moved, he had to move a distance of more than $50 \mathrm{~m}$. Trimble GeoXM Global Positioning System (GPS) handheld computers (Trimble Navigation Limited, Sunnyvale, California, USA) with Cybertracker software (Liebenberg 2003) were used to collect data in the field. At the end of each sampling day, all data were transferred to a laptop computer. Fish species status was described according to their stock status (Griffiths, Attwood \& Thomson 1999) and/ or according to their International Union for Conservation of Nature (IUCN) Red List category if they had been assessed (IUCN 2011). Differences in size structure, site-based CPUE and species-based CPUE between the Dwesa and Cwebe sample sites were tested using $t$-tests. Results from the Mbashe sample site were not included in the statistical analysis because of insufficient data.

\section{Results}

\section{Species diversity, status and composition}

A total of 28 species was recorded during the study period (Table 1). The Dwesa site produced more species than the Cwebe site and the Mbashe Estuary (Table 2). Of the total of 28 species, five were cartilaginous fish and 23 were bony fish species. Line fish species diversity varied between the sites, with 17 fish families being sampled in total and the Dwesa sample site producing 15, the Cwebe sample site 13 and the Mbashe only four families (Table 2). Twelve of the species sampled were southern African endemics, with the Dwesa sample site producing 11, the Cwebe sample site 10 and the Mbashe site zero (Table 2). The stock status of the species sampled included one optimally exploited, three over-exploited, six collapsed, 14 unknown and three probably over-exploited or collapsed species (Table 2; Mann 2000). One species was classified as endangered, two were classified as vulnerable, two near-threatened and two least concern, according to the IUCN Red List for threatened species (Table 2; IUCN 2011). These included two serranid species and the rest were cartilaginous species. The other 21 species, which were all bony fish species, have not had their conservation status evaluated except for L. lithognathus, which was listed as 'lower risk/conservation dependent', by older IUCN criteria (Table 2).

The most abundant fish species caught in the MPA during the study period were from the families sparidae, sciaenidae, serranidae and rhinobatidae (Table 1). Species such as
Austroglossus sp., Gymnothorax undulatus and Amblyrhynchotes honckenii, which technically are not typical line-fish species, were occasionally sampled, but were included in the results for species inventory purposes (Table 1).

\section{Size composition}

Only a few species were sampled in sufficient numbers in order to compare size composition between the different sample sites. These included Pachymetopon grande, Diplodus sargus capensis, Argyrosomus japonicus, Epinephelus andersoni and Rhinobatos annulatus. Although less abundant, P. grande in the Dwesa sample site were significantly larger than those in the Cwebe sample site (Figure 2a and Table 3).

Differences in sizes of D. s. capensis between those caught in the Dwesa and Cwebe sites were not significant (Figure 2b and Table 3). Argyrosomus japonicus sampled in the Mbashe were smaller than those caught in the surf-zone (Figure 2c). However, there was no significant difference between the size of $A$. japonicus sampled in the Dwesa and Cwebe sample sites (Figure 2c and Table 3). Epinephelus andersoni showed similar size frequency distributions within the two sample sites (Figure 2d and Table 3). There was also no significant difference between the sizes of $R$. annulatus caught in the Dwesa versus the Cwebe sample sites (Figure 2e and Table 3).

\section{Catch per unit effort Sample site catch per unit effort}

The overall CPUE for all sites sampled in the Dwesa-Cwebe MPA was 0.71 fish.angler ${ }^{-1}$.hour ${ }^{-1}+0.48$ SD; $N=191$. The CPUE in the Dwesa sample site $\left(0.84\right.$ fish.angler $^{-1}$.hour ${ }^{-1}+$ $0.49 \mathrm{SD} ; N=94)$ was significantly higher $(P=<0.0001)$ than that in the Cwebe sample area $\left(0.57\right.$ fish.angler $^{-1}$.hour ${ }^{-1}+$ $0.43 \mathrm{SD} ; N=89$ ) (Figure 3 and Table 4 ). The highest CPUE was achieved during the July 2009 sampling trip and the lowest during the February 2010 sampling trip (Figure 3). The first Mbashe Estuary sampling trip produced a similar CPUE (0.83 fish.angler ${ }^{-1}$.hour ${ }^{-1}+0.43 \mathrm{SD} ; N=8$ ) to the Dwesa sample site (Figure 3 and Table 4 ).

\section{Species-specific catch per unit effort}

The CPUE for $P$. grande was similar during the different sampling trips, with a peak in the Cwebe sampling site during July 2009 (Figure 4a). The CPUE for this species was significantly lower at the Dwesa sample site compared to the Cwebe sampling site (Table 4).

Catches of D. s. capensis peaked in July 2009 at both sites and the CPUE for D. s. capensis was significantly lower in the Cwebe sample site compared to the Dwesa sample site (Figure $4 \mathrm{~b}$ and Table 4 ). The CPUE of A. japonicus was highly variable (Figure 4c). The CPUE for this important species was significantly higher in the Dwesa sample site than in the Cwebe sample site (Figure 4c and Table 4). A high CPUE (0.44 fish.angler ${ }^{-1}$.hour ${ }^{-1} \pm 0.33 \mathrm{SD} ; N=8$ ) of small A. japonicus was recorded in the Mbashe Estuary during the 
TABLE 1: A list of the fish species sampled in the Dwesa-Cwebe Marine Protected Area with the percentage composition indicated.

\begin{tabular}{|c|c|c|c|c|c|c|c|c|}
\hline Type & Family & Species & Common name & $\begin{array}{l}\text { Total number } \\
\text { sampled }\end{array}$ & Total (\%) & Dwesa (\%) & Cwebe (\%) & Mbashe (\%) \\
\hline \multirow[t]{4}{*}{ Cartilaginous fish } & Dasyatidae & Dasyatis chrysonota & Blue ray & 4 & 0.38 & 0.16 & 0.25 & 0.00 \\
\hline & Rhinobatidae & Rhinobatos annulatus & Lesser sandshark & 91 & 8.55 & 7.07 & 9.65 & 17.31 \\
\hline & Triakidae & Triakis megalopterus & Spotted gullyshark & 4 & 0.38 & 0.33 & 0.50 & 0.00 \\
\hline & Scyliorhinidae & Haploblepharus fuscus & Brown shy shark & 1 & 0.09 & 0.16 & 0.00 & 0.00 \\
\hline \multirow[t]{21}{*}{ Bony fish } & Ariidae & Galeichthys feliceps & White barbel & 8 & 0.75 & 1.32 & 0.00 & 0.00 \\
\hline & & Dichistius multifasciatus & Banded Galjoen & 7 & 0.66 & 0.33 & 1.24 & 0.00 \\
\hline & Cynoglossidae & Austroglossus sp. & Sole & 1 & 0.09 & 0.16 & 0.00 & 0.00 \\
\hline & Haemuliidae & Pomadasys commersonnii & Spotted grunter & 7 & 0.66 & 0.00 & 0.00 & 13.46 \\
\hline & Muraenidae & Gymnothorax undulatus & Leopard moray & 11 & 1.03 & 1.15 & 0.99 & 0.00 \\
\hline & Plotosidae & Plotosus nkunga & Eeltail barbel & 25 & 2.35 & 3.14 & 1.96 & 0.00 \\
\hline & Pomatomidae & Pomatomus saltatrix & Elf & 3 & 0.28 & 0.33 & 0.25 & 0.00 \\
\hline & Sciaenidae & Argyrosomus japonicus & Dusky kob & 173 & 16.26 & 16.45 & 10.64 & 57.69 \\
\hline & Scorpididae & Neoscorpis lithophilus & Stone bream & 23 & 2.16 & 0.82 & 4.46 & 0.00 \\
\hline & Serranidae & Epinephelus andersoni & Catface rockcod & 75 & 7.05 & 9.05 & 4.95 & 0.00 \\
\hline & & Epinephelus marginatus & Yellow belly rockcod & 30 & 2.82 & 3.62 & 1.98 & 0.00 \\
\hline & Sparidae & Acanthopagrus vagus & River bream & 6 & 0.56 & 0.00 & 0.00 & 11.54 \\
\hline & & Cymatoceps nasutus & Black musselcracker & 7 & 0.66 & 0.99 & 0.25 & 0.00 \\
\hline & & Rhabdosargus holubi & Cape stumpnose & 5 & 0.47 & 0.49 & 0.50 & 0.00 \\
\hline & & Rhabdosargus sarba & Natal stumpnose & 3 & 0.28 & 0.49 & 0.00 & 0.00 \\
\hline & & Diplodus sargus capensis & Blacktail & 320 & 30.08 & 38.32 & 21.53 & 0.00 \\
\hline & & Pachymetopon grande & Bronze bream & 214 & 20.11 & 11.51 & 35.64 & 0.00 \\
\hline & & Sparodon durbanensis & White musselcracker & 7 & 0.66 & 0.66 & 0.74 & 0.00 \\
\hline & & $\begin{array}{l}\text { Diplodus cervinus } \\
\text { hottentotus }\end{array}$ & Zebra & 11 & 1.03 & 0.99 & 1.24 & 0.00 \\
\hline & & $\begin{array}{l}\text { Lithognathus } \\
\text { lithognathus }\end{array}$ & White steenbras & 5 & 0.47 & 0.66 & 0.25 & 0.00 \\
\hline & Tetraodontidae & $\begin{array}{l}\text { Amblyrhynchotes } \\
\text { honckenii }\end{array}$ & Evileye blaasop & 1 & 0.09 & 0.00 & 0.25 & 0.00 \\
\hline
\end{tabular}

TABLE 2: A summary of the species caught (number of families and species) and their stock status according to Mann (2000) and their International Union for Conservation of Nature Red List categorisation.

\begin{tabular}{|c|c|c|c|c|c|}
\hline Description & Category & Dwesa & Cwebe & Mbashe & Total \\
\hline \multirow[t]{3}{*}{ Taxonomic } & Number of species & 25 & 22 & 4 & 28 \\
\hline & Number of families & 15 & 13 & 4 & 17 \\
\hline & Number of endemic species & 11 & 10 & 0 & 12 \\
\hline \multirow[t]{5}{*}{ Status } & Under-exploited & 0 & 0 & 0 & 0 \\
\hline & Optimally exploited & 1 & 1 & 0 & 1 \\
\hline & Over-exploited & 3 & 2 & 0 & 3 \\
\hline & Unknown & 13 & 10 & 2 & 14 \\
\hline & Unknown but probably over-exploited or collapsed & 3 & 3 & 0 & 3 \\
\hline \multirow{6}{*}{$\begin{array}{l}\text { IUCN Red List } \\
\text { Category }\end{array}$} & Critically endangered & 0 & 0 & 0 & 0 \\
\hline & Endangered & 1 & 1 & 0 & 1 \\
\hline & Vulnerable & 2 & 1 & 0 & 2 \\
\hline & Near Threatened & 2 & 2 & 0 & 2 \\
\hline & Not evaluated & 17 & 15 & 4 & 20 \\
\hline & Lower risk/conservation dependant $\dagger$ & 1 & 1 & 0 & 1 \\
\hline
\end{tabular}

Source: IUCN, 2011, IUCN Red List of Threatened Species Version 2011.2, Retrieved 12 April 2012, from http://www.iucnredlist.org/

IUCN, International Union for Conservation of Nature.

$\dagger$, Old criteria assessment (Skelton, P., 1996, Lithognathus lithognathus, IUCN Redlist, Retrieved 08 June 2011, from http://www.iucnredlist.org/).

first sampling trip conducted there in October 2010. Catches of E. andersoni stayed relatively stable over the first six sampling trips (Figure 4d). The CPUE for E. andersoni was significantly lower in the Cwebe sample site in comparison with the Dwesa sample site (Figure $4 \mathrm{~d}$ and Table 4). There was no significant difference in the CPUE for R. annulatus between the Dwesa and Cwebe sample sites (Figure 4e and Table 4).

\section{Ethical considerations}

ECPTA have adopted the standard SAIAB ethical procedures for handling aquatic organisms and research was conducted under permits issued through the Department of Environmental Affairs and the Department of Agriculture, Forestry and Fisheries. 


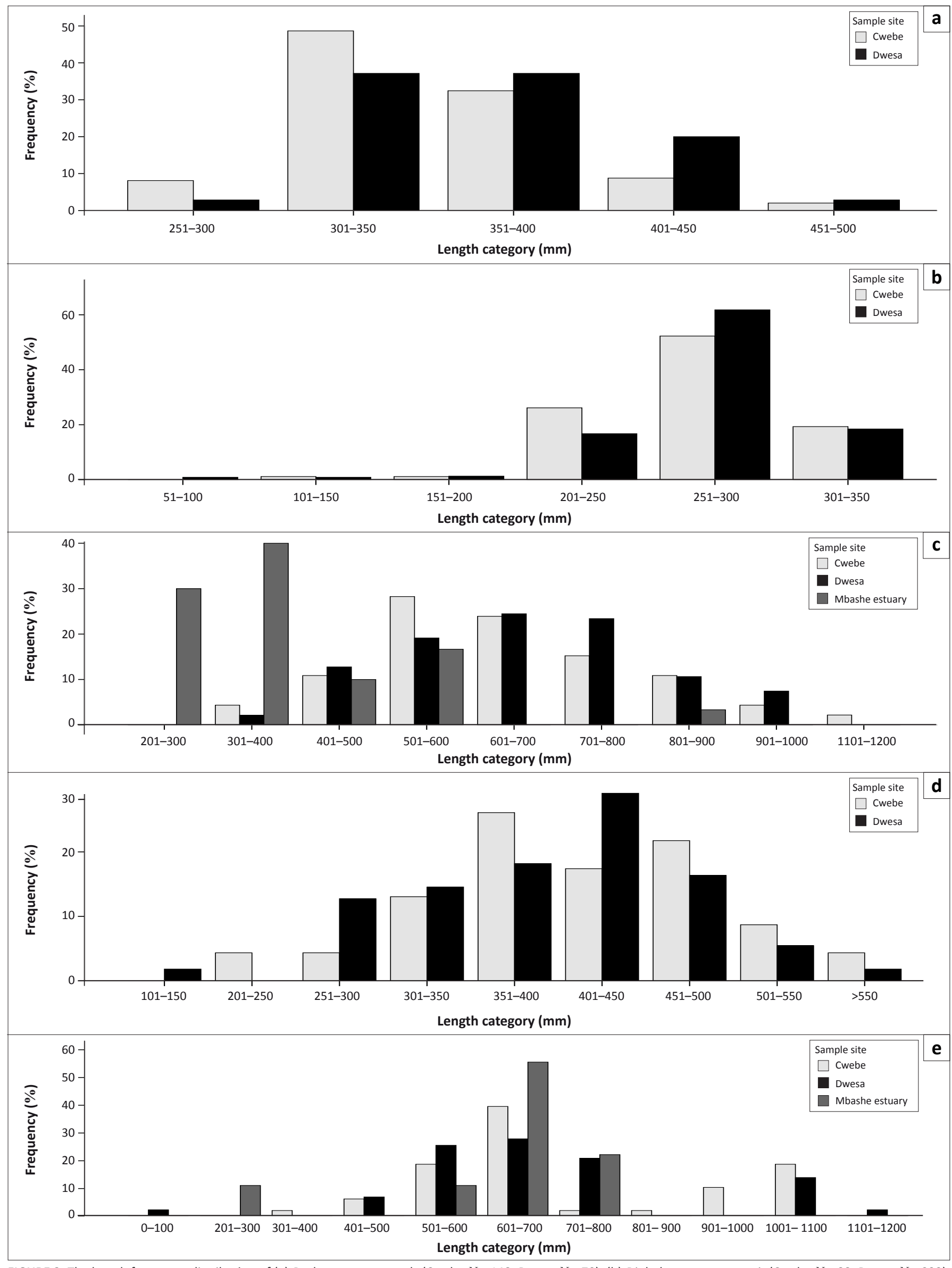

FIGURE 2: The length frequency distribution of (a) Pachymetopon grande (Cwebe $N=148$; Dwesa $N=70$ ), (b) Diplodus sargus capensis (Cwebe $N=88$; Dwesa $N=233$ ), (c) Argyrosomus japonicus (Cwebe $N=46$; Dwesa $N=94$; Mbashe $N=30$ ), (d) Epinephelus andersoni (Cwebe $N=23$; Dwesa $N=55$ ) and (e) Rhinobatos annulatus (Cwebe $N=54$; Dwesa $N=51$; Mbashe $N=11$ ) in the Dwesa, Cwebe and Mbashe sample areas. 


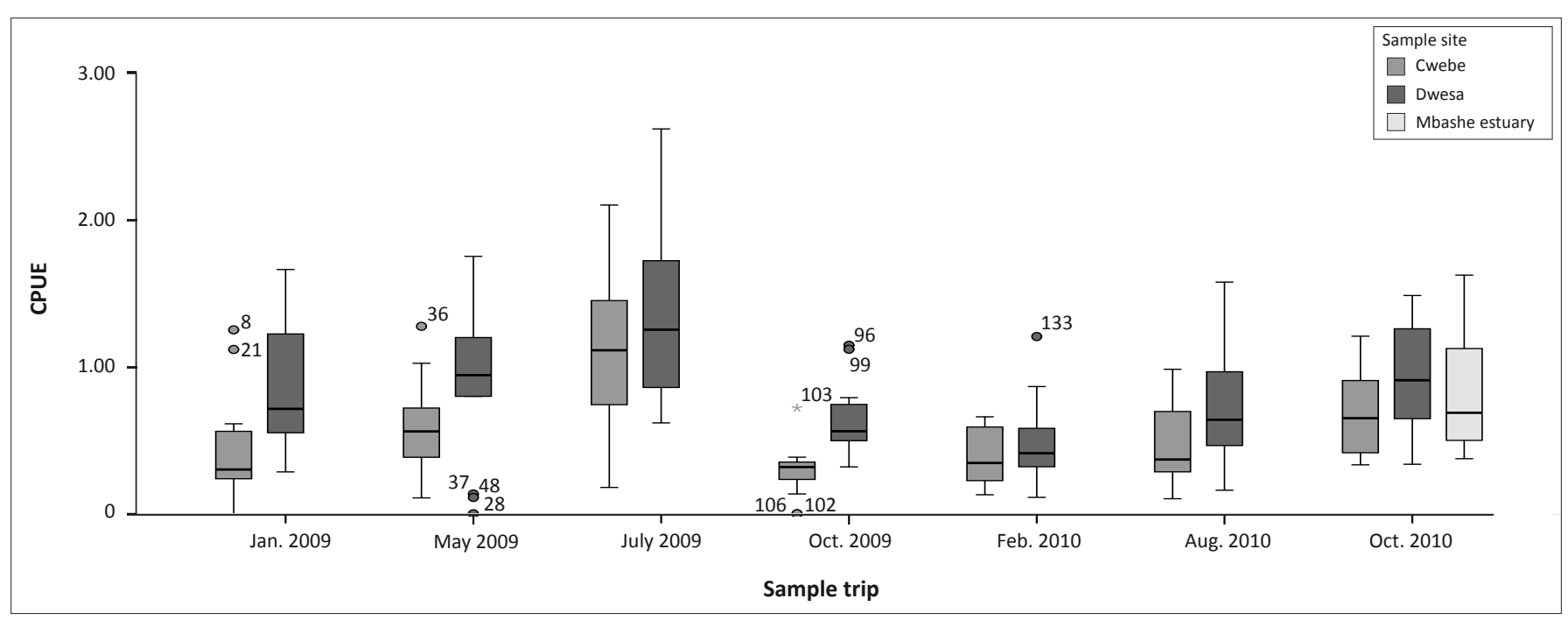

CPUE, catch per unit effort.

FIGURE 3: The catch per unit effort recorded at the three different sampling sites during seven field trips conducted between January 2009 and October 2010.

TABLE 3: Results of the statistical comparison of mean fish sizes between the Dwesa and Cwebe sample sites for five dominant species sampled in the Dwesa-Cwebe Marine Protected Area.

\begin{tabular}{|c|c|c|c|c|c|c|c|c|c|}
\hline \multirow[t]{2}{*}{ Species } & \multirow[t]{2}{*}{$N$} & \multicolumn{2}{|c|}{ Dwesa sampling site } & \multirow[t]{2}{*}{$N$} & \multicolumn{2}{|c|}{ Cwebe sampling site } & \multirow[t]{2}{*}{$t$} & \multirow[t]{2}{*}{$d f$} & \multirow[t]{2}{*}{$p$} \\
\hline & & Mean & s.d. & & Mean & s.d. & & & \\
\hline Pachymetopon grande & 70 & 367.54 & 41.979 & 148 & 352.65 & 36.943 & 2.658 & 216 & 0.008 \\
\hline Diplodus sargus capensis & 233 & 274.71 & 35.710 & 88 & 273.10 & 33.202 & 0.379 & 167.554 & 0.705 \\
\hline Argyrosomus japonicus & 94 & 668.91 & 146.058 & 46 & 640.02 & 166.212 & 1.004 & 79.914 & 0.318 \\
\hline Epinephelus andersoni & 55 & 397.16 & 82.726 & 23 & 414.96 & 87.357 & -0.833 & 39.341 & 0.410 \\
\hline Rhinobatos annulatus & 43 & 688.26 & 218.879 & 48 & 726.23 & 206.250 & -0.849 & 86.489 & 0.398 \\
\hline
\end{tabular}

s.d., standard deviation; $t$, $t$-test; $d f$, degrees of freedom; $p$, $p$-value.

Significant values are indicated in bold.

\section{Discussion}

Cognisance must be taken of the preliminary nature of the results presented in this paper, which span a period of only two years and seven field trips. Götz, Cowley and Winkler (2008) recommend a minimum of four years' sampling. However, the pressure currently being placed on the authorities responsible for the management of the DwesaCwebe MPA to open up parts of the reserve to subsistence and recreational shore-angling warranted analysis and publication of these results in order to help guide the decision-making process.

The 28 species sampled during the current study period represent only $72 \%$ of the possible 39 inshore line-fish species likely to occur in the Dwesa-Cwebe MPA, based on the results of an earlier survey of the lower Transkei coast (Mann et al. 2003). Other studies in the former Transkei area also produced more species and families (Table 5) (Mann et al. 2003; Pradervand 2004). These studies were based on roving-creel as well as shore-angling competition data and spanned a large proportion of the Wild Coast shoreline. In the case of the competition data (Pradervand 2004), these were collected over a substantially longer time period (19772000), from the Umtamvuna to the Mbashe River. Further afield, the Port of Ngqura (Dicken 2010), Tsitsikamma MPA (Götz et al. 2008) and the Goukamma MPA (Dicken 2010; Götz et al. 2008; Pradervand \& Hiseman 2006) were also more species diverse than the Dwesa-Cwebe MPA (Table 5). However, as only one sampling method was used during the current study (i.e. shore-angling), the number of fish species sampled was limited. A variety of sampling methods, which include line-fishing, underwater visual surveys, seine netting and possibly rotenone collections (for small cryptic species), over a long time period, are needed to enable compilation of a comprehensive fish species list for an MPA (Wood et al. 2000). Further sampling is thus needed in the Dwesa-Cwebe MPA to establish a more comprehensive fish species list.

Several overexploited and collapsed line-fish species were present in the Dwesa-Cwebe MPA as a whole. Some were relatively abundant (e.g. A. japonicus, E. andersoni and P. grande), whilst other species were less abundant (e.g. Dichistius capensis, Pomatomus saltatrix, Umbrina robinsoni, Epinephelus marginatus, Cymatoceps nasutus, Rhabdosargus sarba, Sparodon durbanensis and L. lithognathus). The redlisted species for which IUCN assessments currently exist included only serranids and a few elasmobranch species. These included one endangered species (E. marginatus), two vulnerable species (Carcharius taurus and Haploblepharus fuscus) and two near-threatened species (E. andersoni and Triakis megalopterus). The only other species with red-listed status was the endemic sparid L. lithognathus (Skelton 1996). The assessment for L. lithognathus was done using older redlisting criteria and needs to be re-assessed (IUCN 2011). The process of red-listing South African sparids and sciaenids is 


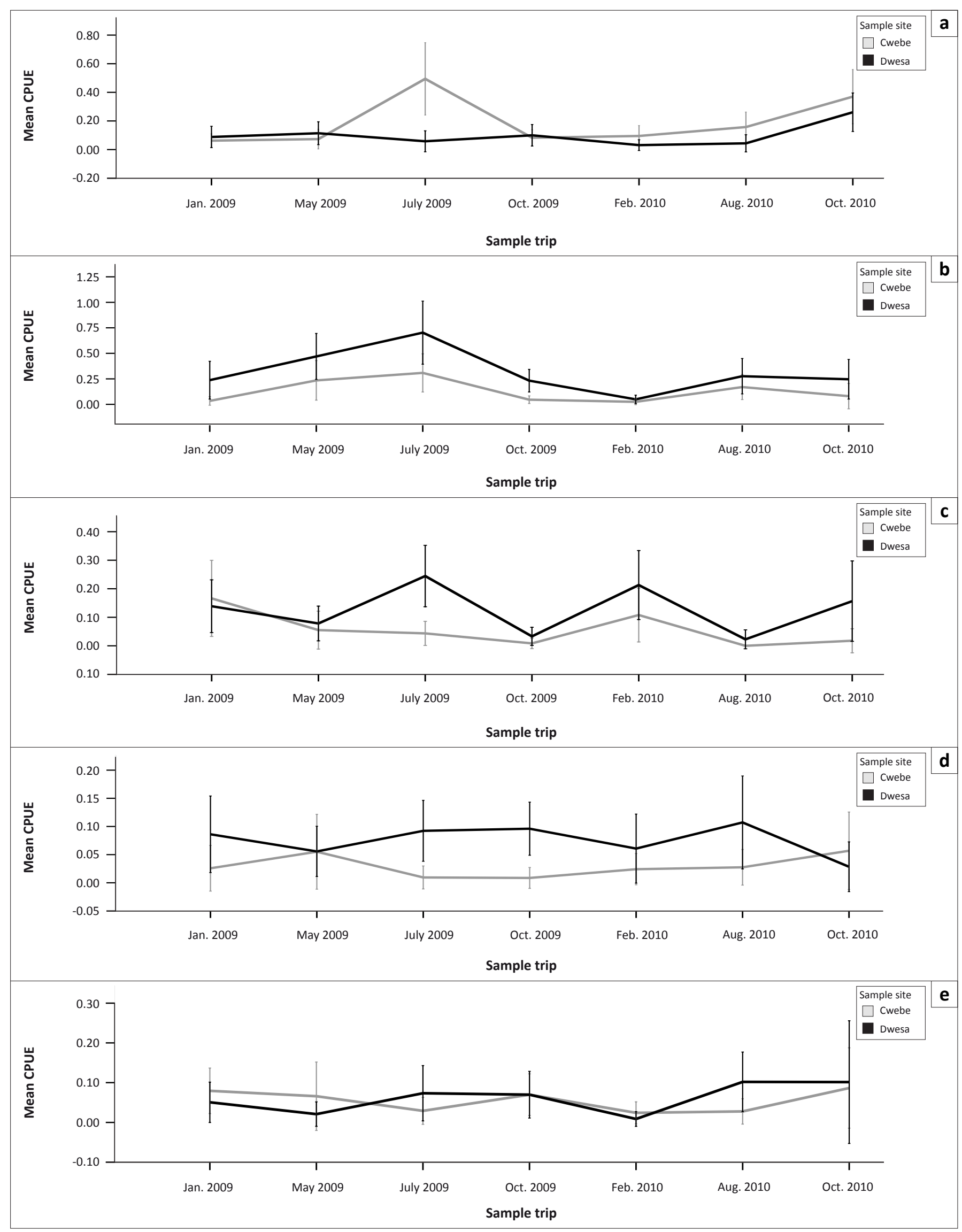

Error bars indicate standard deviation.

CPUE, catch per unit effort.

FIGURE 4: The catch per unit effort for five dominant species (a) Pachymetopon grande, (b) Diplodus sargus capensis, (c) Argyrosomus japonicus, (d) Epinephelus andersoni and (e) Rhinobatos annulatus, in the different sample sites in the Dwesa-Cwebe Marine Protected Area during seven sampling trips conducted between January 2009 and October 2010. 
TABLE 4: The results of the comparison of catch per unit effort between the Dwesa and Cwebe sample sites for five dominant species sampled in the Dwesa-Cwebe Marine Protected Area. Age at 50\% maturity and maximum age are also indicated.

\begin{tabular}{|c|c|c|c|c|c|c|c|c|c|c|c|}
\hline \multirow[t]{2}{*}{ Species } & \multirow[t]{2}{*}{$\begin{array}{l}\text { Age at } 50 \% \\
\text { maturity }\end{array}$} & \multirow[t]{2}{*}{$\begin{array}{l}\text { Maximum } \\
\text { age }\end{array}$} & \multirow[t]{2}{*}{$N$} & \multicolumn{2}{|c|}{$\begin{array}{c}\text { Dwesa } \\
\text { sampling site }\end{array}$} & \multirow[t]{2}{*}{$N$} & \multicolumn{2}{|c|}{$\begin{array}{c}\text { Cwebe } \\
\text { sampling site }\end{array}$} & \multirow[t]{2}{*}{$t$} & \multirow[t]{2}{*}{$d f$} & \multirow[t]{2}{*}{$p$} \\
\hline & & & & Mean & s.d. & & Mean & s.d. & & & \\
\hline Pachymetopon grande & 5.5 & 38 & 94 & 0.0869 & 0.1332 & 89 & 0.1884 & 0.2730 & -3.227 & 181.00 & 0.0010 \\
\hline Argyrosomus japonicus & 5.0 & 45 & 94 & 0.1276 & 0.1682 & 89 & 0.0565 & 0.1299 & 3.252 & 181.00 & 0.0010 \\
\hline Epinephelus andersoni & 4.4 & 11 & 94 & 0.0788 & 0.1044 & 89 & 0.0268 & 0.0606 & 4.095 & 181.00 & $<0.0001$ \\
\hline All species & - & - & 94 & 0.8379 & 0.4899 & 89 & 0.5687 & 0.4271 & 3.969 & 179.79 & $<0.0001$ \\
\hline
\end{tabular}

Source: Source given is only applicable to column 2 and column 3. Mann, B.Q., 2000, South African linefish status reports, Oceanographic Research Institute Durban s.d., standard deviation; $t, t$-test; $d f$, degrees of freedom; $p, p$-value.

Significant values are indicated in bold.

currently underway and the results should be available by the end of 2012 (B. Mann, March 2012 ORI, pers. obs.). A high proportion of the species sampled (53\%) had some level of concern in terms of their stock status (or red-list status) and 43\% were southern African endemics. This highlights the importance of the Dwesa-Cwebe MPA for the protection of threatened line-fish stocks. These results are not surprising considering that the MPA falls within an important transition zone between the Agulhas and Natal bio-regions (Lombard et al. 2004; Maree et al. 2000). The MPA can thus be considered to be of high conservation importance in terms of these criteria (Bond 1989; Wood et al. 2000).

The three most abundant species caught in the Dwesa-Cwebe MPA were D. s. capensis, P. grande and A. japonicus. In other areas of the former Transkei, outside proclaimed MPAs, the most abundant species were $P$. saltatrix, D. s. capensis, R. annulatus, P. grande and Sphyrna sp. (Table 5) (Mann et al. 2003; Pradervand 2004). Further south, in the Goukamma MPA, the most abundant species were D. S. capensis, D. capensis and Sarpa salpa (Table 5) (Pradervand \& Hiseman 2006), whilst in the Tsitsikamma MPA, D. s. capensis, D. capensis and Boopsoidea inornata were the most abundant species caught from the shore (Götz et al. 2008). The main difference between the above areas and the Dwesa-Cwebe MPA was the abundance of $A$. japonicus and $P$. grande. Only the Port of Ngqura, which is not a formally protected area, had similar abundances of $A$. japonicus (Dicken 2010). Inclusion of the Mbashe Estuary as a third sampling site in October 2010 revealed a high catch rate of juvenile A. japonicus suggesting that this estuary provides an important nursery area for this species. This was confirmed by current research being conducted in the Mbashe Estuary (N. James, SAIAB, April 2011 pers. comm.). This emphasises the importance of the Dwesa-Cwebe MPA for the protection of this heavily overexploited species.

Within the MPA, the Dwesa sample site had a higher number of species than the Cwebe sample site (Table 2) and a significantly higher CPUE, suggesting higher fish abundance (Table 4). Two major factors could be influencing this comparison. One is the difference in surf-zone habitat structure between the two sample sites and the other is the level of illegal exploitation. No surveys have been done to quantify the differences in habitat structure, but from on-site observation, both sites appear to be very similar in nature.
Within the surf-zone both sites have sandy substrata, broken rock and sand, rocky reefs and rocky points. With regard to illegal exploitation, there was clear evidence of higher levels of illegal exploitation of fish in the Cwebe sample site. This is not surprising, considering its closer proximity to the hotel, holiday cottages and community areas. This evidence is further supported by the higher number of illegal activities reported by the MPA's field rangers in the Cwebe area (ECPTA unpublished data).

These preliminary results thus suggest that illegal fishing on the Cwebe side of the MPA may be having an impact on the surf-zone line-fish community. In addition to this, several species-specific observations were made during the current survey. There was a higher relative abundance of $D$. s. capensis, E. andersoni and A. japonicus in the Dwesa sample area compared to the Cwebe sample area. All these species are relatively slow growing and reach a maximum age of $>10$ years (Cowley et al. 2001; Fennessy 1998). Species with these life history characteristics typically produce a lower yield per unit stock and have a slower rate of recovery following overexploitation (Buxton \& Clarke 1989; Cowley et al. 2001). No-take MPAs are therefore frequently recommended as an important tool (in addition to conventional fisheries management regulations) to ensure effective protection and rebuilding of overexploited stocks of species of this nature (Bennett \& Attwood 1991; Attwood \& Bennett 1995; Cowley et al. 2001; Mann et al. 2006). No-take MPAs help to allow exploited fish stocks to recover by placing a portion of the population off-limits to users. Setting aside a no-take MPA is similar to limiting fishermen in terms of catch and/or effort, or any similar management strategy that effectively decreases fish mortality (Byers \& Noonburg 2007; Gell \& Roberts 2003; Goni et al. 2010). Illegal exploitation could potentially eliminate the positive effect of fish dispersal (known as spillover) from MPAs (Byers \& Noonburg 2007). Byers and Noonburg (2007) also predict that an initial large investment in enforcement efforts would provide the greatest return on maintaining the benefits of the MPA to the fishery of an area.

The comparison of length frequencies between the two study areas was less revealing, with only P. grande showing evidence of significantly larger size classes present in the Dwesa sample site compared to the Cwebe sample site. Surprisingly, very few L. lithognathus ( $0.47 \%$ of the total catch) were sampled during the study. This is cause for concern, as the beaches adjacent to the Mbashe mouth were historically 
TABLE 5: A comparison of fishery statistics between Dwesa-Cwebe Marine Protected Area and a number of other areas in South Africa.

\begin{tabular}{|c|c|c|c|c|c|c|c|c|c|c|c|c|}
\hline \multirow[t]{3}{*}{ Area } & \multirow{3}{*}{$\begin{array}{l}\text { Time } \\
\text { period }\end{array}$} & \multirow[t]{3}{*}{ Method } & \multirow{3}{*}{$\begin{array}{l}\text { Number } \\
\text { species }\end{array}$} & \multirow{3}{*}{$\begin{array}{l}\text { Number } \\
\text { families }\end{array}$} & \multirow[t]{3}{*}{ CPUE } & \multicolumn{6}{|c|}{ Most dominant species } & \multirow[t]{3}{*}{ Reference } \\
\hline & & & & & & \multicolumn{2}{|l|}{ 1st } & \multicolumn{2}{|l|}{ 2nd } & \multicolumn{2}{|l|}{ 3rd } & \\
\hline & & & & & & Species & $\%$ & Species & $\%$ & Species & $\%$ & \\
\hline $\begin{array}{l}\text { Goukamma MPA, } \\
\text { Western Cape }\end{array}$ & $\begin{array}{l}1993- \\
2002\end{array}$ & $\begin{array}{l}\text { Voluntary } \\
\text { catch cards }\end{array}$ & 35 & 15 & 0.89 & $\begin{array}{l}\text { Diplodus sargus } \\
\text { capensis }\end{array}$ & 39 & $\begin{array}{l}\text { Dichistius } \\
\text { capensis }\end{array}$ & 25 & $\begin{array}{l}\text { Sarpa } \\
\text { salpa }\end{array}$ & 8 & $\begin{array}{l}\text { Pradervand } \\
\text { and Hiseman } \\
(2006)\end{array}$ \\
\hline $\begin{array}{l}\text { Tsitsikamma MPA, } \\
\text { Western and } \\
\text { Eastern Cape }\end{array}$ & $\begin{array}{l}1998- \\
2005\end{array}$ & $\begin{array}{l}\text { Catch and } \\
\text { release }\end{array}$ & 55 & 21 & 1.01 & $\begin{array}{l}\text { Diplodus sargus } \\
\text { capensis }\end{array}$ & 24 & $\begin{array}{l}\text { Dichistius } \\
\text { capensis }\end{array}$ & 11 & $\begin{array}{l}\text { Boopsoidea } \\
\text { inornata }\end{array}$ & 8 & $\begin{array}{l}\text { Götz et al. } \\
\text { (2008) }\end{array}$ \\
\hline $\begin{array}{l}\text { Wild Coast, } \\
\text { Eastern Cape }\end{array}$ & $\begin{array}{l}1997- \\
1998\end{array}$ & $\begin{array}{l}\text { Roving } \\
\text { creel }\end{array}$ & 39 & 23 & 0.12 & $\begin{array}{l}\text { Pomatomus } \\
\text { saltatrix }\end{array}$ & 18 & $\begin{array}{l}\text { Diplodus sargus } \\
\text { capensis }\end{array}$ & 16 & $\begin{array}{c}\text { Pachymetopon } \\
\text { grande }\end{array}$ & 12 & $\begin{array}{l}\text { Mann et al. } \\
(2003)\end{array}$ \\
\hline $\begin{array}{l}\text { Wild Coast, } \\
\text { Eastern Cape }\end{array}$ & $\begin{array}{l}1977- \\
2000\end{array}$ & $\begin{array}{l}\text { Competition } \\
\text { records }\end{array}$ & 71 & 34 & - & $\begin{array}{l}\text { Pomatomus } \\
\text { saltatrix }\end{array}$ & 19 & $\begin{array}{l}\text { Rhinobatos } \\
\text { annulatus }\end{array}$ & 13 & $\begin{array}{l}\text { Sphyrna } \\
\text { spp. }\end{array}$ & 11 & $\begin{array}{l}\text { Pradervand } \\
(2004)\end{array}$ \\
\hline $\begin{array}{l}\text { Dwesa-Cwebe MPA, } \\
\text { Eastern Cape }\end{array}$ & $\begin{array}{l}2009- \\
2010\end{array}$ & $\begin{array}{l}\text { Catch and } \\
\text { release }\end{array}$ & 28 & 17 & 0.72 & $\begin{array}{l}\text { Diplodus sargus } \\
\text { capensis }\end{array}$ & 30 & $\begin{array}{l}\text { Pachymetopon } \\
\text { grande }\end{array}$ & 20 & $\begin{array}{l}\text { Argyrosomus } \\
\text { japonicus }\end{array}$ & 16 & $\begin{array}{l}\text { Venter and } \\
\text { Mann } \\
(2012)\end{array}$ \\
\hline
\end{tabular}

Source: Mann et al. 2003; Pradervand 2004; Pradervand \& Hiseman 2006; Gotz et al. 2008; Dicken 2010

CPUE, catch per unit effort.

Note: Please see the full reference list of the article, Venter, J.A. \& Mann, B.Q., 2012, 'Preliminary assessment of surf-zone and estuarine line-fish species of the Dwesa-Cwebe Marine Protected Area, Eastern Cape, South Africa', Koedoe 54(1), Art. \#1059, 10 pages. http://dx.doi.org/10.4102/koedoe.v54i1.1059, for more information.

well-known for catches of this species, particularly during late winter (July-September) when adults formed large spawning aggregations (Bennett 1993).

Although preliminary, the results of this study show that there are significant localised differences within the MPA that are probably caused by illegal exploitation. Significant improvements in law enforcement and education are therefore needed in the Dwesa-Cwebe MPA, in order to decrease the current negative effects of illegal exploitation of fish. Furthermore, it is also recommended that the current no-take status of the MPA should not be changed and that alternative options should be explored to improve socioeconomic conditions within the local communities living adjacent to the Dwesa-Cwebe MPA.

\section{Conclusion}

This is the first baseline species list that has been developed for the Dwesa-Cwebe MPA. The 28 line-fish species recorded in this study include a significant number of nationally and even globally important species from a conservation perspective. Important information regarding the biology of various key species (i.e. length frequency and relative abundance) was collected during this study, which could help inform future conservation management of the MPA. This study has also highlighted the regional importance of the Dwesa-Cwebe MPA by comparing it to other areas along the Wild Coast and further afield. However due to the preliminary nature of this study it is strongly advised that this monitoring project should be continued for a minimum of at least another three years to enable a more reliable evaluation to be made of the effectiveness of this MPA.

\section{Acknowledgements}

We would like to thank the volunteers, especially Daniel Fourie, Keith Funnel, Gerhard Barnard, Harry Steyn and Schalk Steyn, who give up their valuable time to assist with field sampling. Paul Cowley provided valuable assistance during the conception of the project. Colin Attwood, Chantelle Radue and Dave Balfour provided useful comments on earlier drafts of this manuscript. Funding for the study was provided by the Eastern Cape Parks and Tourism Agency, as well as the Department of Environmental Affairs.

\section{Competing interests}

The authors declare that they have no financial or personal relationship(s) which may have inappropriately influenced them in writing this paper.

\section{Authors' contributions}

J.A.V. (Eastern Cape Parks and Tourism Agency) was the project leader, was responsible for experimental design, conducted all field work and performed all data analysis. B.Q.M. (Oceanographic Research Institute) was involved in the conceptualisation of the project, helped train field workers and gave substantial input in preparing the manuscript.

\section{References}

Attwood, C.G., 2003, 'Dynamics of the fishery for Galjoen Dischistius capensis, with assessment of monitoring methods', African Journal of Marine Science 25, 311330. http://dx.doi.org/10.2989/18142320309504020

Attwood, C.G. \& Bennett, B.A., 1995, 'Modelling the effect of marine reserves on the recreational shore-fishery of the south-western Cape, South Africa', South African Journal of Marine Science 16, 227-240. http://dx.doi. org/10.2989/025776195784156458

Bennett, B.A., 1993, 'Aspects of the biology and life history of white steenbras Lithognathus lithognathus in southern Africa', South African Journal of Marine Science 13, 83-96. http://dx.doi.org/10.2989/025776193784287257

Bennett, B.A. \& Attwood, C.G., 1991, 'Evidence for recovery of a surf-zone fish assemblage following the establishment of a marine reserve on the southern
coast of South Africa', Marine Ecology Progress Series 75, 173-181. http://dx.doi. org/10.3354/meps075173

Bond, W.J., 1989, 'Describing and conserving biotic diversity', in B.J. Huntley (ed.), Biotic diversity in Southern Africa: Concepts and conservation, pp. 2-18, Oxford University Press, Cape Town.

Buxton, C.D. \& Clarke, J.R., 1989, 'The growth of Cymatoceps nasutus (Teleostei: Sparidae), with comments on diet and reproduction', South African Journal of Marine Science 8, 57-65. http://dx.doi.org/10.2989/02577618909504551

Byers, J.E. \& Noonburg, E.G., 2007, 'Poaching, enforcement, and the efficacy of marine Reserves', Ecological Applications 17, 1851-1856. http://dx.doi.org/10.1890/070067.1, PMid:17974326

Cowley, P.D., Brouwer, S.L. \& Tilney, R.L., 2001, 'The role of the Tsitsikamma National Park in the management of four shore-angling fish along the South-Eastern Cape Coast of South Africa', South African Journal of Marine Science 24, 1-9.

Dicken, M.L., 2010, 'The ichthyofauna in the Port of Ngqura, South Africa', African Journal of Marine Science 32, 491-499. http://dx.doi.org/10.2989/181423 2X.2010.538139

ECPTA, 2010, Unpublished field ranger records containing data on law enforcement activities, Dwesa-Cwebe Nature Reserve, Willowvale. 
Fennessy, S.T., 1998, Biology and stock assessment of Serranidae, Oceanographic Research Institute, Durban.

Fielding, P., 2010, Dwesa-Cwebe status report and scientific recommendations, Department of Enivironmental Affairs: Oceans and Coast, Cape Town.

Fielding, P., Robertson, W.D., Dye, A.H., Tomalin, B.J., Van der Elst, R.P., Beckley, L.E. et al., 1994, Transkei coastal fisheries resources, Oceanographic Research Institute, Durban.

Gell, F.R. \& Roberts, C.M., 2003, 'Benefits beyond boundaries: The fishery effects of marine reserves', Trends in Ecology and Evolution 18, 448-455. http://dx.doi. org/10.1016/S0169-5347(03)00189-7

Goni, R., Hilborn, R., Diaz, D., Mallol, S. \& Adlerstein, S., 2010, 'Net contribution of spillover from a marine reserve to fishery catches', Marine Ecology Progress Series 400, 233-243. http://dx.doi.org/10.3354/meps08419

Götz, A., Cowley, P.D. \& Winkler, H., 2008, 'Selected fishery and population parameters of eight shore-angling species in the Tsitsikamma National Park notake marine reserve', African Journal of Marine Science 30, 519-532. http:// dx.doi.org/10.2989/AJMS.2008.30.3.7.641

Griffiths, M.H., Attwood, C.G. \& Thomson, R., 1999, 'New management protocol for the South African linefishery', in B.Q. Mann (ed.), Third Southern African Marine Linefish Symposium, pp. 145-156, SANCOR, Arniston.

IUCN, 2011, IUCN Red List of Threatened Species Version 2011.2, Retrieved April 2012, from http://www.iucnredlist.org/

Kerwath, S.E., Götz, A., Attwood, C.G. \& Sauer, W.H.H., 2008, 'The effect of marine protected areas on an exploited population of sex-changing temperate reef fish An individual-based model', African Journal of Marine Science 30, 337-350. http://dx.doi.org/10.2989/AJMS.2008.30.2.10.560

Liebenberg, L., 2003, Towards a worldwide environmental monitoring network, Cybertracker, Cape Town. Retrieved May 19, 2012, from http://www.cybertracker. org/index.php?option=com_content\&view=article\&id=140\&ltemid=125

Lombard, A.T., Strauss, T., Harris, J., Sink, K., Attwood, C. \& Hutchings, L., 2004, 'South African National Spatial Biodiversity Assessment: Marine Component', NSBA Technical Reports, South African National Biodiversity Institute, Pretoria.
Mann, B.Q., 2000, South African linefish status reports, Oceanographic Research Institute Durban.

Mann, B.Q., Celliers, L., Fennessy, S.T., Bailey, S. \& Wood, A.D., 2006, 'Towards the declaration of a large marine protected area: A subtidal ichthyo-faunal survey of the Pondoland coast in the Eastern Cape, South Africa', African Journal of Marine Science 28, 535-551. http://dx.doi.org/10.2989/18142320609504204

Mann, B.Q., MacDonald, A.M., Sauer, W.H.H. \& Hecht, T., 2003, 'Evaluation of participation in and management of the Transkei shore linefishery', South African Journal of Marine Science 25, 79-97. http://dx.doi. South African Journal of $M$ orir
org/10.2989/18142320309504002

Maree, R.C., Booth, A.J. \& Whitfield, A.K., 2000, 'Effect of water temperature on the biogeography of South African estuarine fishes associated with the subtropical/ warm temperate subtraction zone', South African Journal of Science 96, 184-188.

McClanahan, T.R. \& Mangi, S., 2000, 'Spillover of exploitable fishes from a marine park and its effect on the adjacent fishery', Ecological Applications 10, 1792-1805. park and its effect on the adjacent fishery', Ecological Applications 10, 1792

Pradervand, P., 2004, 'Long-term trends in the shore fishery of the Transkei coast, South Africa', African Zoology 39, 247-261.

Pradervand, P. \& Hiseman, R., 2006, 'An analysis of the recreational shore fishery in the Goukamma Marine Protected Area', African Zoology 41, 275-289. http:// dx.doi.org/10.3377/1562-7020(2006)41[275:AAOTRS]2.0.CO;2

Skelton, P., 1996, Lithognathus lithognathus, IUCN Redlist, Retrieved 08 June 2011 from http://www.iucnredlist.org/

Turpie, J.K., Adams, J.B., Joubert, A., Harrison, T.D., Collothy, B.M., Maree, R.C. et al., 2002, 'Assessment of the conservation priority status of South African estuaries for use in management and water allocation', Water SA 28, 16. http://dx.doi. org $/ 10.4314 /$ wsa.v28i2.4885

Wood, A.D., Brouwer, S.L., Cowley, P.D. \& Harrison, T.D., 2000, 'An updated check list of the ichthyofaunal assemblage of the Tsitsikamma National Park, South Africa', Koedoe 43, 83-95. 